\title{
Hubungan Hasil Dipstik Urin (Leukosit Esterase, Nitrit dan Glukosuria) dengan Kejadian ISK pada Pegawai
}

\section{The Relationship between Urine Dipstic Results (Leukocyte Esterase, Nitrite, and Glucosuria) with UTI in Employees}

\author{
Maria Tuntun ${ }^{1}$, Siti Aminah ${ }^{2}$ \\ Jurusan Analis Kesehatan, Politeknik Kesehatan Tanjungkarang, Indonesia
}

\section{ARTICLE INFO}

\section{Article history}

Received date

05 Oct 2021

Revised date

09 Nov 2021

Accepted date

24 Nov 2021

\section{Keywords:}

Culture;

Dipstick;

Urine;

UTI.

\section{Kata kunci:}

Kultur;

Dipstik;

Urin;

ISK.

\begin{abstract}
ABSTRAK
A urine test with a dipstick is an alternative test for rapid leukocyte and bacterial tests to support the diagnosis of urinary tract infection (UTI). The purpose of this study was to determine the relationship between the results of the dipstick test (leukocyte esterase, nitrite, and glucosuria) with the incidence of UTI. The research is observational analytic with a cross-sectional design, which was conducted in September-October 2020, at Campus "X". The population is 351 people, with 92 respondents. A urine test was performed with a dipstick and culture. The dipstick test is a screening step, while the culture is used to confirm the microbiological diagnosis of UTI. The results of the study using the dipstick test showed that 17 people $(18,48 \%)$ were positive for leukocyte esterase, 27 people $(29,35 \%)$ were positive for nitrite, and 7 people $(7,61 \%)$ were positive for glucosuria (DM). The results of the urine culture test showed that 20 people $(21,74 \%)$ had UTI, which consisted of 11 women and 9 men. There is a relationship between leukocyte esterase and nitrite on UTI (p-value 0.00), but there is no relationship between glucosuria and UTI (p-value 0,279). The use of the dipstick test as a screening test for the incidence of UTI has been used, but it is still necessary to continue with a culture test to be able to make a diagnosis of UTI.
\end{abstract}

\begin{abstract}
Pemeriksaan urin dengan alat dipstik adalah suatu tes alternatif uji leukosit dan bakteri secara cepat untuk mendukung penegakkan diagnosa ke arah infeksi saluran kemih (ISK). Tujuan penelitian ini untuk mengetahui adanya hubungan antara hasil uji dipstik (leukosit esterase, nitrit dan glukosuria) dengan kejadian ISK. Jenis penelitian adalah analitik observasional dengan desain cross-sectional, yang dilakukan pada September-Oktober 2020, di Kampus "X". Populasi sebanyak 351 orang, dengan responden penelitian sebanyak 92 orang. Pemeriksaan urin dilakukan dengan dipstik dan kultur. Uji dengan dipstik merupakan langkah skrining, sedangkan kultur untuk menegakan diagnosa ISK secara mikrobiologi. Hasil penelitian dengan uji dipstik menemukan 17 orang $(18,48 \%)$ positif leukosit esterase, 27 orang $(29,35 \%)$ positif nitrit, dan 7 orang $(7,61 \%)$ mengalami positif glukosuria (DM). Dengan uji kultur urin menunjukkan 20 orang $(21,74 \%)$ mengalami ISK, yang terdiri dari 11 orang wanita dan 9 orang pria. Terdapat hubungan antara keberadaan leukosit esterase dan nitrit terhadap ISK ( $p$-value 0,00), tetapi tidak ada hubungan antara diabetes melitus dengan ISK (p-value 0,279). Penggunaan tes dipstik sebagai uji skrining kejadian ISK dapat digunakan, namun tetap harus melanjutkan dengan uji kultur untuk dapat menegakkan diagnosa ISK.
\end{abstract}

\section{PENDAHULUAN}

Penyakit infeksi saluran kemih (ISK) perlu mendapatkan penanganan yang cepat untuk menegakkan diagnosa laboratorium. Beberapa meode pemeriksaan telah dikembangkan agar dapat dilakukan dengan cepat dan hasil yang akurat. Seringkali penyakit ISK ini tidak menimbulkan gejala klinis yang berat, namun memberikan hasil positif ketika dilakukan 
pemeriksaan laboratorium, sehingga hal ini perlu menjadi perhatian bagi klinisi dalam menangani penyakit ISK ini. Selain itu ada beberapa faktor predisposisi untuk terjadinya ISK, diantaranya adalah penyakit diabetes melitus (DM). Pada penderita DM lebih mudah terjadinya infeksi bakteri, karena kadar gula yang tinggi menjadi nutrisi bagi bakteri untuk tumbuh dan berkembang biak. Pada penderita DM ditandai dengan hasil positif pada pemeriksaan glukosa urin dipstiknya, dan disebut dengan istilah glukosuria.

Sampai saat ini pemeriksaan kultur urin merupakan gold standard untuk menegakkan diagnosa ISK. Kelemahan pemeriksaan kultur ini adalah butuh waktu yang lama (3-5 hari) dan biaya yang tinggi, serta laboratorium khusus untuk melakukan pemeriksaan ini (Najeeb, 2015).

Ada beberapa metode pilihan untuk uji laboratorium penegakkan diagnosa ISK, diantaranya dengan metode rapid tes yang menggunakan alat dipstik urin. Uji dengan alat dipstik urin sering digunakan sebagai skrining kejadian ISK. Pada alat dipstik urin yang diamati adalah leukosit esterase dan nitrit untuk menetapkan diagnosis ISK. Pemeriksaan leukosit esterase merupakan indikator terjadinya piuria dan pemeriksaan nitrit merupakan indikator adanya bakteriuria (Mambatta, 2015)

Pemeriksaan leukosit esterase pada dipstik yaitu berdasarkan kemampuan leukosit esterase dalam menghidrolisis asam ester yang menghasilkan senyawa aromatik. Warna ungu yang terbentuk berkorelasi dengan jumlah leukosit esterase dalam urin. Tes nitrit yang positif pada dipstik menunjukkan adanya bakteri dalam urin, yang dapat mereduksi nitrat menjadi nitrit (Schmiemann, 2010).

Penggunaan dipstik urin telah dilakukan secara luas di dunia, banyak Negara menggunakan alat ini sebagai investigasi awal dalam menentukan ISK di fasilitas pelayanan kesehatan. Pengoperasian alat dipstik sangat mudah, biaya pemeriksaannya pun tidak mahal, sehingga menjadi pilihan sebagai alat skrining penyakit ISK (Jharna, 2015; Mambatta, 2015).

Tingkat sensitivitas dan spesifisitas alat dipstik ini sangat bervariasi. Berdasarkan penelitian yang telah dilakukan didapatkan data yaitu Agpaoa (2015) mendapatkan sensitivitas $(95,2 \%)$ dan spesifisitas $(82,3 \%$,$) ; Demille$ (2014) mendapatkan sensitivitas dari leukosit esterase $71,4 \%$, spesifisitasnya $90 \%$, dan sensitivitas dari nitrit $57,7 \%$, spesifisitas $96,7 \%$; Mambatta (2015) mendapatkan sensitivitas nitrit $23,31 \%$ dan sensitivitas leukosit esterase 48,5\%; Ginting (2018) mendapatkan nilai sensitivitas
$88.2 \%$, dan spesifisitas 98.7\%; Negara, CA (2018) mendapatkan nilai sensitivitas $89,28 \%$ dan spesifisitas $56,71 \%$.

Walaupun hasil penelitian banyak yang menunjukkan nilai sensitivitas dan spesifisitas yang bervariasi, namun secara klinis hasil pemeriksaan urin yang menunjukkan hasil positif pada pemeriksaan nitrit dan leukosit esterase dapat menjadi skrining kejadian ISK, terutama di daerah yang belum mempunyai laboratorium untuk melakukan kultur. Jika hasil pemeriksaan leukosit esterase negatif, maka belum tentu responden tidak mengalami ISK. Dan jika hasil nitrit negatif, maka belum tentu tidak ada bakteri dalam urin (Duane, 2013). Jika terjadi hal tersebut maka pemeriksaan harus dilanjutkan dengan pemeriksaan kultur urin sebagai diagnosa laboratorium untuk mengetahui kejadian ISK. Penelitian ini bertujuan untuk mengetahui adanya hubungan antara hasil uji dipstik (leukosit esterase, nitrit dan glukosuria) dengan kejadian ISK (hasil kultur urin).

\section{METODE}

Penelitian ini merupakan penelitian potong lintang/desain cross sectional. Penelitian dilakukan pada bulan September-Oktober 2020, di Kampus " $X$ " yang berada di Bandar Lampung. Populasi dalam penelitian ini seluruh pegawai yang bekerja di Kampus "X". Responden yang diambil urin nya adalah yang memenuhi kriteria inklusi, diantaranya bersedia menjadi responden dalam penelitian, berusia $\geq 18$ tahun, baik pria dan wanita, mengalami salah satu resiko ISK (infeksi saluran kemih) seperti sering menahan buang air kecil, pernah menderita ISK sebelumnya, pernah mengalami batu ginjal, sering mengompol tanpa disadari, dan menderita penyakit kencing manis (ditandai dengan hasil pemeriksaan glukosa urin positif).

Pemeriksaan urin dilakukan di laboratorium Bakteriologi Jurusan Analis Kesehatan, Poltekkes Tanjungkarang. Alat dan bahan yang digunakan diantaranya dipstik urin, $\mathrm{BSC}$, inkubator, autoclave, petri dish, ose, tabung reaksi, media PCA, media nutrien agar. Pemeriksaan urin dengan rapid tes menggunakan dipstik urin serta dilakukan kultur urin secara konvensional untuk melihat pertumbuhan koloni bakterinya. Pemeriksaan urin menggunakan dipstik dilakukan mengikuti prosedur alatnya, yaitu strip dipstiknya dicelupkan kedalam urin selama satu menit, lalu dibaca hasilnya dengan menggunakan standar alat dipstik. Leukosit esterase dibaca setelah dua menit, sedangkan 
nitrit dan glukosuria (penentuan DM) dibaca setelah satu menit. Jumlah koloni bakteri yang tumbuh pada kultur/media perbenihan digunakan untuk penentuan kategori ISK. Penentuan kategori ISK ini sesuai dengan Kementerian Kesehatan RI (2014), yaitu Kategori 1 didapatkan jumlah koloni bakteri $<10^{4}$ per $\mathrm{ml}$ urin, dan dinyatakan tidak mengalami ISK. Pada kategori 2 , didapatkan antara $10^{4-1} 10^{5}$ koloni per ml urin, dalam hal ini kemungkinan ada ISK, sedangkan kategori 3 didapatkan lebih dari $10^{5}$ koloni per $\mathrm{ml}$ urin, dan responden mengalami ISK, walaupun tidak terlihat gejala klinis. Data yang didapat dianalisis secara univariat untuk melihat distribusi frekuensi setiap variabel, dan dianalisis secara bivariat dengan uji chi-square untuk melihat adanya hubungan antar variabel (data hasil pemeriksaan leukosit esterase, nitrit, glukosuria terhadap hasil kultur urin). Penelitian ini telah mendapatkan persetujuan dari Komisi Etik Penelitian Kesehatan Poltekkes Tanjungkarang dengan nomor: 267/KEPKTJK/V/2020 tanggal 23 Mei 2020.

\section{HASIL}

Tabel 1. Distribusi Frekuensi Responden Berdasarkan Jenis Kelamin

\begin{tabular}{lcc}
\hline Variabel & $\mathbf{f}$ & $\boldsymbol{\%}$ \\
\hline Pria & 29 & 31,53 \\
Wanita & 63 & 68,47 \\
\hline
\end{tabular}

Penelitian ini diikuti oleh responden wanita $(68,47 \%)$ lebih banyak dari responden pria $(3,53 \%)$, karena jumlah pegawai Kampus "X" lebih banyak berjenis kelamin wanita dibandingkan pria.

Tabel 2. Distribusi Frekuensi Responden Berdasarkan Umur

\begin{tabular}{lrrr}
\hline Variabel & Rata-rata & $\begin{array}{c}\text { Umur } \\
\text { terendah }\end{array}$ & $\begin{array}{c}\text { Umur } \\
\text { tertinggi }\end{array}$ \\
\hline $\begin{array}{l}\text { Umur } \\
\text { responden }\end{array}$ & 44,43 & 23 & 61 \\
\hline
\end{tabular}

Responden yang terlibat dalam penelitian ini rata-rata berumur 44,43 tahun, dengan umur termuda yaitu 23 tahun dan tertua 61 tahun.

Hasil pemeriksaan dipstik urin meliputi pemeriksaan leukosit esterase, nitrit dan glukosuria, yang merupakan uji skrining terhadap adanya ISK (infeksi saluran kemih) dapat dilihat pada tabel 3 .

Tabel 3. Hasil Pemeriksaan Leukosit Esterase, Nitrit dan Diabetes Mellitus pada Responden

\begin{tabular}{lrrrr}
\hline \multicolumn{1}{c}{ Variabel } & Negatif & \multicolumn{1}{c}{$\%$} & Positif & \multicolumn{1}{c}{$\%$} \\
\hline Leukosit & 75 & 81.52 & 17 & 18.48 \\
esterase & 65 & 70,65 & 27 & 29.35 \\
Nitrit & 85 & 92.39 & 7 & 7.61 \\
Glukosuria & & & & \\
\hline
\end{tabular}

Dari 92 responden yang diperiksa urinnya, terbanyak hasil positif pada pemeriksaan nitrit $(29,35 \%)$. Pemeriksaan leukosit esterase positif sebanyak $18,48 \%$ dan yang paling sedikit yaitu glukosuria positif sebanyak 7,61\%. Hasil pemeriksaan kultur urin yang dipakai untuk menentukan kategori ISK.

Tabel 4. Hasil Pemeriksaan Kultur Urin untuk Penentuan Kategori ISK

\begin{tabular}{lrr}
\hline Kategori ISK & \multicolumn{1}{c}{$\begin{array}{c}\text { Jumlah } \\
\text { responden }\end{array}$} & \multicolumn{1}{c}{$\%$} \\
\hline Kategori 1 & 66 & 71,74 \\
Kategori 2 & 6 & 6,52 \\
Kategori 3 & 20 & 21,74 \\
Total & 92 & 100 \\
\hline
\end{tabular}

Hasil pemeriksaan kultur kategori 1 dan 2 tidak dinyatakan ISK. Hanya kategori 3 yang dinyatakan ISK. Pada kategori 3 didapatkan 20 responden yang terdiri dari 11 orang wanita $(55 \%)$ dan 9 orang pria $(45 \%)$, yang dinyatakan mengalami ISK.

Hasil analisis bivariat untuk mengetahui hubungan antara hasil leukosit esterase, hasil nitrit dan DM terhadap kejadian ISK (hasil pemeriksaan kultur) dapat dilihat pada tabel 5 . 
Tabel 5. Hubungan antara Hasil Leukosit Esterase (LE), Nitrit dan Glukosuria (DM) terhadap Kejadian ISK

\begin{tabular}{|c|c|c|c|c|c|c|c|c|c|}
\hline \multirow{3}{*}{ Jenis Kelamin } & \multirow{3}{*}{ Uji } & \multirow{3}{*}{ Hasil } & \multicolumn{6}{|c|}{ Kategori ISK } & \multirow{3}{*}{ p-value } \\
\hline & & & \multicolumn{2}{|c|}{ Kategori 1} & \multicolumn{2}{|c|}{ Kategori 2} & \multicolumn{2}{|c|}{ Kategori 3} & \\
\hline & & & Jumlah & $\%$ & Jumlah & $\%$ & Jumlah & $\%$ & \\
\hline \multirow{2}{*}{ Wanita } & \multirow{2}{*}{ LE } & negatif & 49 & 90,7 & 5 & 9,3 & 0 & 0,0 & 0,000 \\
\hline & & positif & 0 & 0,0 & 0 & 0,0 & 11 & 100,0 & \\
\hline \multirow{2}{*}{ Pria } & \multirow{2}{*}{ LE } & negatif & 17 & 81,0 & 1 & 4,8 & 3 & 14,3 & \\
\hline & & positif & 0 & 0,0 & 0 & 0,0 & 6 & 100,0 & \\
\hline \multirow{2}{*}{ Wanita } & \multirow{2}{*}{ nitrit } & negatif & 48 & 100,0 & 0 & 0,0 & 0 & 0,0 & 0,000 \\
\hline & & positif & 1 & 5,9 & 5 & 29,4 & 11 & 64,7 & \\
\hline \multirow{2}{*}{ Pria } & \multirow{2}{*}{ nitrit } & negatif & 17 & 100,0 & 0 & 0,0 & 0 & 0,0 & \\
\hline & & positif & 0 & 0,0 & 1 & 10,0 & 9 & 90,0 & \\
\hline \multirow{2}{*}{ Wanita } & \multirow{2}{*}{ Glukosuria } & negatif & 44 & 73,3 & 5 & 8,3 & 11 & 18,3 & 0,279 \\
\hline & & positif & 5 & 100,0 & 0 & 0,0 & 0 & 0,0 & \\
\hline \multirow{2}{*}{ Pria } & \multirow{2}{*}{ Glukosuria } & negatif & 16 & 64,0 & 0 & 0,0 & 9 & 36,0 & \\
\hline & & positif & 1 & 50,0 & 1 & 50,0 & 0 & 0,0 & \\
\hline
\end{tabular}

\section{PEMBAHASAN}

Infeksi saluran kemih (ISK) merupakan salah satu penyakit yang didominasi oleh kaum wanita sebagai penderita terbanyak, seperti yang ditemui pada penelitian ini, yaitu jumlah responden wanita $(68,47 \%)$ lebih banyak dibandingkan pria $(31,53 \%)$ yang dapat dilihat pada tabel 1. Demikian juga dengan hasil kultur (tabel 4) yang termasuk kategori 3 didominasi oleh wanita $(55 \%)$ daripada pria $(45 \%)$. ISK merupakan penyakit yang diderita oleh kebanyakan kaum hawa dibandingkan pria. Beberapa temuan hasil penelitian, seperti Bellazreg (2019), Herlina (2019) dan Marques (2017) juga mendapatkan jumlah wanita lebih banyak dari pria yang menderita ISK (Bellazreg, 2019; Marques, 2017; Herlina, 2019). Besarnya risiko wanita menderita ISK, disebabkan kondisi uretra yang pendek, serta tingkat kelembaban daerah kewanitaan yang merupakan kondisi menguntungkan bagi bakteri untuk tumbuh dan berkembangbiak. Sehingga bakteri dapat naik ke saluran kemih mulai dari uretra lalu ke kandung kemih (Jawetz, 2017).

Penelitian ini diikuti oleh 92 responden, dengan usia rata-rata 44,43 tahun. Usia termuda 23 tahun dan usia tertua 61 tahun (tabel 2). ISK dapat menyerang siapa saja, mulai dari usia bayi sampai lansia, seperti yang disampaikan oleh Herlina (2015) dalam penelitiannya yang mendapatkan nilai $\mathrm{p}$ value sebesar 0,119 yang berarti tidak ada hubungan antara usia dengan kejadian ISK ( $p$-value $>0,05)$

Tes untuk mengetahui adanya infeksi saluran kemih (ISK) dapat menggunakan alat dipstik urin. Dipstik ini sebagai salah satu rapid tes yang segera dapat mengetahui hasil pemeriksaannya, sehingga sangat membantu klinisi untuk mengambil keputusan uji laboratorium selanjutnya (Seputra, 2015).

Parameter uji pada tes dipstik untuk penentuan ISK diantaranya uji leukosit esterase dan nitrit (Grabe, 2015). Pada tabel 3, hasil tes dipstik dinyatakan $17(18,48 \%)$ orang positif pemeriksaan leukosit esterase. Hasil penelitian ini seperti yang didapatkan oleh Inayati (2014) yaitu sebanyak $60,7 \%$ responden dinyatakan positif leukosit esterase.

Keberadaan leukosit dalam urin dapat dideteksi oleh tes dipstik berdasarkan reaksi leukosit esterase, yaitu enzim yang dihasilkan oleh sel leukosit (granula sel netrofil, basophil dan eosinophil) (Schmiemann, 2010). Leukosit esterase menghidrolisis ester dan menghasilkan reaksi azocoupling yang ditandai dengan warna beige berubah menjadi violet (Schwartz, 2006). Hasil positif pada uji leukosit esterase dengan alat dipstik, sering menunjukkan hasil yang kurang spesifik dikarenakan adanya piuria. Beberapa penyakit seperti urethritis, nefrophati, adanya tumor pada kandung kemih menyumbang leukosit dalam urin. Keadaan ini menyebabkan nilai prediksi positif uji leukosit esterase mempunyai rentang yang panjang, dari 19\% 88\% (Mambatta, 2015).

Hasil uji nitrit yang positif dalam penelitian ini didapatkan 27 (29,35\%) orang. Uji nitrit pada tes dipstik berdasarkan kemampuan bakteri merubah nitrat menjadi nitrit dengan pertolongan enzim nitrat reduktase, enzim nitrit oksid reduktase dan nitrous oksid reduktase. Bakteri yang sering ditemukan dalam urin merupakan kelompok bakteri Gram negative (Seputra, 2015), dari family Enterobacteriaceae termasuk sebagian besar bakteri non-fermenter (Mambatta, 2015). Hasil negatif palsu dapat disebabkan urin belum mencapai 4 jam dalam 
kandung kemih (Bellazreg, 2019). Hasil uji nitrit yang negatif tidak dapat mengesampingkan kejadian ISK. Hasil ini dapat terjadi jika alat dipstik yang dipakai mempunyai sensitivitas yang rendah (Thakre, 2012).

Tidak dapat dipungkiri bahwa telah banyak diketahui dari hasil penelitian sebelumnya, banyak penelitian sejenis yang menggunakan dipstik mendapatkan data sensitivitas dan spesivisitas yang rendah pada hasil pemeriksaan leukosit esterase dan nitrit. Demile (2014) dan Eigbefoh (2008) melakukan penelitian yang mendapatkan data positif palsu dan negatif pada pemeriksaan leukosit esterase dan nitrit dengan alat dipstik untuk mendiagnosa ISK. Namun demikian alat dipstik ini masih merupakan pilihan untuk melakukan skrining adanya ISK dengan cepat (Demilie, et al., 2014; Eigbefoh, 2008).

Responden yang disertai DM dalam penelitian ini sebanyak 7 orang $(7,61 \%)$, namun semua responden tersebut tidak ada yang masuk kategori 3 yang berarti tidak ada responden yang menderita DM mengalami ISK. Penelitian ini sejalan dengan hasil penelitian Widiatmoko (2019) yang mendapatkan bahwa tidak ada pasien DM yang positif ISK, walaupun sebanyak $67,24 \%$ pasien DM menyebutkan mengalami gejala ISK ringan (Widiatmoko, 2019). Namun penelitian ini berbeda dengan hasil yang ditemukan oleh Mgbakogu (2015) di Nigeria yang menemukan prevalensi sekitar $26 \%$, Saraswati (2018) mendapatkan 21,2\% di Yogyakarta (Mgbakogu, 2015; Saraswati, 2018).

Kultur urin merupakan pemeriksaan gold standar untuk memastikan diagnosa ISK. Jika jumlah koloni bakteri uropatogen yang tumbuh lebih dari $10^{5} \mathrm{cfu} / \mathrm{ml}$, yang diambil dari 2 sampel urin midstream, maka dinyatakan terkena ISK walaupun tidak terlihat gejala klinis (Seputra, 2015).

Berdasarkan data pada tabel 4, hasil kultur urin didapatkan sebanyak 66 responden $(71,74 \%)$ termasuk kategori 1, sebanyak 6 responden $(6,52 \%)$ kategori 2 , dan 20 responden $(21,74 \%)$ merupakan kategori 3. Responden yang mengalami ISK berdasarkan hasil kultur ini didapatkan 11 orang wanita $(55 \%)$ dan 9 orang pria $(45 \%)$. Wanita yang mengalami ISK lebih banyak dibandingkan pria.

\section{Hubungan Antara Hasil Uji Dipstik (Leukosit Esterase, Nitrit Dan Glukosuria) dengan Kejadian ISK}

Hasil analisis bivariat (tabel 5) dapat dilihat bahwa ada hubungan antara hasil uji leukosit esterase terhadap kejadian ISK ( $p$ value
0,00). Hal ini menandakan bahwa adanya leukosit dalam urin merupakan petunjuk telah terjadi infeksi oleh bakteri. Leukosit jenis netrofil merupakan bagian dari sIstem imun yang berfungsi untuk membunuh bakteri. Hasil leukosit esterase positif baik pada wanita maupun pria hanya dijumpai pada kategori 3. Ini menunjukan korelasi antara adanya leukosit (bakteri) yang diperiksa dengan leukosit esterase dengan hasil kultur. Hasil kultur dinyatakan kategori 3 jika pertumbuhan koloni bakterinya lebih dari $10^{5} \mathrm{CFU} / \mathrm{ml}$. Pada kategori 1 dan kategori 2 didapatkan tidak ada hasil leukosit esterase yang positif, ini bukan berarti tidak ada leukosit dalam sampel urin. Hasil penelitian ini seperti yang diperoleh Malau (2019) yang mendapatkan hubungan antara leukosit esterase dengan kultur urin ( $\mathrm{p}$ value 0,044 ).

Beberapa kelemahan pemeriksaan leukosit esterase yang menyebabkan hasil negatif palsu, yaitu adanya protein dan glukosa dalam urin, berat jenis urin yang tinggi, penggunaan antibiotic dan kadar asam askorbat dalam urin yang tinggi. Sedangkan hasil positif palsu dapat disebabkan beberapa hal, seperti pengambilan sampel yang tidak tepat pada wanita (urin terkontaminasi dengan cairan dari vagina), adanya trichomonas, agen oksidasi dan formalin (Brunzel, 2004).

Untuk hasil nitrit positif dapat dijumpai pada responden dengan kategori 1,2 dan 3 untuk responden wanita, sedangkan untuk responden pria hanya pada kategori 2 dan 3 (tabel 5). Berdasarkan hasil analisis biavariat didapatkan hubungan antara nitrit dengan kejadian ISK dengan p-value 0,000. Keadaan ini dapat menjelaskan bahwa adanya bakteri dalam urin dapat menyebabkan hasil yang positif baik dalam tes nitrit maupun dalam kultur. Walaupun pada kultur tumbuh koloni bakteri (kategori 1 dan 2) tetapi belum tentu dinyatakan ISK, karena ada kriteria untuk penentuan diagnosis ISK berdasarkan hasil kultur. Dinyatakan ISK jika hasil kulturnya adalah kategori 3. Hasil penelitian ini tidak sejalan dengan penelitian Malau (2019) yang tidak mendapatkan hubungan antara nitrit dengan kultur urin ( $p$-value 0,272 )

Beberapa kelemahan pada uji nitrit diantaranya hasil negatif palsu karena bakteri yang terdapat di urin bukan bakteri penghasil nitrit, atau proses metabolisme nitrat menjadi nitrit sangat cepat, sehingga hanya sesaat saja berada dalam urin. Makan sayuran seperti selada dan bayam dapat memberikan hasil positif palsu pada pemeriksaan nitrit dalam urin, karena sayuran tersebut mengandung nitrit, tetapi hasil kulturnya negatif 
Sesuai pada tabel 5 hasil uji bivariat dinyatakan tidak ada hubungan antara DM dengan kejadian ISK dengan $p$-value sebesar $0,279$ ( $p$-value $>0,05)$. Ada 5 responden wanita dan 2 responden pria yang menderita DM, dengan hasil kultur termasuk kategori 1 dan 2, sehingga dinyatakan tidak mengalami ISK. Hardiyati (2018) dalam penelitiannya mendapatkan bahwa umur ( $p$-value 0,026 ) dan jenis kelamin ( $p$-value 0,009$)$ berhubungan dengan kejadian ISK pada penderita DM. Wanita dengan DM kemungkinan 4 kali lebih besar mengalami ISK, sedangkan penderita DM dewasa mempunyai peluang 3 lebih besar untuk terjangkitnya ISK dibandingkan tanpa DM. Saptaningsih (2012) menemukan resiko 16 kali terkena ISK pada penderita DM wanita berusia lebih dari 60 tahun. Mgbakogu (2015) mengungkapkan prevalensi ISK pada penderita DM sebesar 26\%.

Penderita DM (hasil uji glukosuria positif) memiliki risiko yang tinggi untuk terkena ISK

\section{DAFTAR PUSTAKA}

Agpaoa, V. V., Mendoza, B. J., Fernandezi, A. J. M., Veloso, J. D., \& Bhatnagar, S. (2015). Predict Urinary Tract Infection and to Estimate Causative Bacterial Class in a Philippine Subspecialty Hospital. J Nephrol Ther 5: 194(25) 4-6.

Bellazreg, F., Abid, M., Lasfar, N. B., Hattab, Z., Hachfi, W., \& Letaief, A. (2019). Diagnostic value of dipstick test in adult symptomatic urinary tract infections: results of a cross-sectional Tunisian study. The Pan African Medical Journal, 33 .

Brunzel, N. A. (2004). Fundamentals of Urine and Body Fluid Analysis. WB Saunders Company. Philadelphia. 119-263.

Demilie, T., Beyene, G., Melaku, S., \& Tsegaye, W. (2014). Diagnostic accuracy of rapid urine dipstick test to predict urinary tract infection among pregnant women in Felege Hiwot Referral Hospital, Bahir Dar, North West Ethiopia. BMC research notes, 7(1)1-5.

Duane RH, Victor WN. (2013). Management of Recurrent Urinary Tract Infections in Healthy Adult Women. Reviews in Urology, 15(2): 41-8.

Eigbefoh, J. O., Isabu, P., Okpere, E., \& Abebe, J. (2008). The diagnostic accuracy of the rapid dipstick test to predict asymptomatic urinary tract infection of karena terjadi penurunan sistem kekebalan tubuh, bahkan dapat merusak parenkim ginjal secara luas (Mgbakogu, 2015).

\section{SIMPULAN}

Simpulan hasil penelitian ini didapatkan dari total responden terbanyak mengalami uji nitrit positif, diikuti dengan uji leukosit esterase positif, dan yang paling sedikit uji glukosuria positif (DM). Berdasarkan hasil kultur urin ditemukan lebih banyak wanita mengalami ISK dibandingkan pria.

Ada hubungan antara leukosit esterase dan nitrit terhadap kejadian ISK, tetapi tidak ada hubungan antara glukosuria (DM) dengan kejadian ISK. Penggunaan dipstik untuk melakukan skrining awal diagnosa ISK dapat dilakukan, tetapi menegakkan diagnosa ISK harus melalui uji kultur.

pregnancy. Journal of Obstetrics and Gynaecology, 28(5), 490-495.

Ginting F.,Sugianli A.K., Kusumawati R.L., Parwati I., Jong M.D., Schultsz C., Leth F.V. (2018). Predictive value of the urinary dipstick test in the management of patients with urinary tract infection-associated symptoms in primary care in Indonesia. BMJ, 8: 1-7

Grabe, M., Bartoletti, T.E. ,Bjerklund Johansen., T. Cai. (2015). Guidelines on Urological Infections. European Association of Urology.

Herlina, S., \& Yanah, A. K. M. (2019). Determinan Terjadinya Infeksi Saluran Kemih pada Pasien Dewasa di RSUD Kota Bekasi. Jurnal Ilmiah Kesehatan Masyarakat: Media Komunikasi Komunitas Kesehatan Masyarakat,11(1), 60-71.

Inayati, I., \& Falah, K. (2014). Uji Diagnostik Urinalisis Lekosit Esterase terhadap Kultur Urin pada pasien Infeksi Saluran Kemih (ISK) dengan Kateterisasi Uretra. Syifa'MEDIKA: Jurnal Kedokteran dan Kesehatan, 4(2), 100-108.

Jawetz, E., Melnick, J. L., \& Adelberg, E. (2017). Mikrobiologi kesehatan edisi 27. Penerbit Buku Kesehatan. Jakarta.

Jharna M., Haritha S., and Subitha L. (2015). Utility of dipstick test for the screening of 
urinanry tract infction in catheterized women following gynecological surgeries. Journal of Obstetrics and Gynecology of India, 65 (6): 401-404.

Kementerian Kesehatan RI. (2014). Prosedur pemeriksaan bakteriologi klinik. Jakarta.

Malau, U. N., \& Adipireno, P. (2019). Uji korelasi leukosit esterase dan nitrit dengan kultur urin pada infeksi saluran kemih. Intisari Sains Medis, 10(1), 184-187.

Mambatta, A. K., Jayarajan, J., Rashme, V. L., Harini, S., Menon, S., \& Kuppusamy, J. (2015). Reliability of dipstick assay in predicting urinary tract infection. Journal of family medicine and primary care, 4(2), 265.

Marques, A. G., Pasternak, J., Damascena, M. D. S., França, C. N., \& Martino, M. D. V. (2017). Performance of the dipstick screening test as a predictor of negative urine culture. Einstein (São Paulo), 15, 3439.

Mgbakogu, R. A., \& Eledo, B. O. (2015). Studies on Urinary Tract Infection among Diabetics in Some Eastern States of Nigeria. Studies, 34.

Najeeb S., Munir T., Rehman S., Hafiz A., Gilani M., and Latif M. (2015). Comparison of urine dipstick test with conventional ueine culture in diagnosis of urinary tract infection. Journal of the College of Physicians and Surgeons Pakistan, 25 (2): 108-110.

Negara, C. A. (2018). Ketepatan Pemeriksaan Uji Dipstik Urin dalam Mendiagnosis Infeksi Saluran Kemih (ISK) Nosokomial Simptomatik dan Pola Resistensi ISK Nosokomial di Rumah Sakit Umum Pusat (RSUP) Haji Adam Malik Medan. [Tesis]. Medan: Fakultas Kedokteran, Universitas Sumatera Utara.

Saptaningsih, M. (2012). Determinan Infeksi Saluran Kemih Pada Pasien Diabetes
Mellitus Perempuan di RSB Bandung. [Tesis]. Depok: Fakultas Ilmu Keperawatan Universitas Indonesia.

Saraswati, D., Martini, M., \& Saraswati, L. D. (2018). Gambaran Leukosituria Tanda Infeksi Saluran Kemih Pada Penderita Diabetes Mellitus Tipe-2 (Studi di Wilayah Kerja Puskesmas Ngesrep). Jurnal Kesehatan Masyarakat (Undip), 6(1), 225235.

Seputra, KP., Tarmono., Bambang SG., Chaidir AM., Irfan Wahyudi., Agus Rizal. (2015). Panduan Penatalaksanaan Infeksi Saluran Kemih dan Genitalia Pria. Edisi ke-2. Jakarta . Ikatan Ahli Urologi Indonesia (IAUI).

Schmiemann G, Kniehl E, Gebhardt K, Matejczyk MM, Hummers-Pradier E. The Diagnosis Of Urinary Tract Infection: A Systematic Review. Deutsches Ärzteblatt International. 107(21):361- 367.

Schwartz D, Barone J. (2006). Correlation of urinalysis and dipstick results with catheter-associated urinary tract infections in surgical ICU patients. Intensive Care Med. (32) 1797-1801

Thakre, S. S., Dhakne, S. S., Thakre, S. B., Thakre, A. D., Ughade, S. M., \& Kale, P. (2012). Can the Griess nitrite test and a urinary pus cell count of $\geq 5$ cells per micro litre of urine in pregnant women be used for the screening or the early detection of urinary tract infections in rural India?. Journal of clinical and diagnostic research: JCDR, 6(9), 1518.

Widiatmoko, M. T., Uwan, W. B., \& Mahyarudin, M. (2019). Prevalensi Infeksi Saluran Kemih pada Penderita Diabetes Mellitus Tipe 2 di RSUD Sultan Syarif Mohammad Alkadrie Pontianak. Jurnal Cerebellum, 5(4B), 1559-568. 